\title{
THE INFLUENCE OF TABLE SALT, WHITE SUGAR AND COMPLEX BAKERY ADDITIVE ON THE FERMENTATIVE ACTIVITY OF SACCHAROMYCES CEREVISIAE
}

\section{UTICAJ KUHINJSKE SOLI, KONZUMNOG ŠEĆERA I KOMPLEKSNOG PEKARSKOG ADITIVA NA FERMENTATIVNU AKTIVNOST SACCHAROMYCES CEREVISIAE}

\author{
Vesna M. VUČUROVIĆ, Vladimir S. PUŠKǍ̌, Urǒ̌ D. MILJIĆ, Ana B. MUZALEVSKI \\ University of Novi Sad, Faculty of Technology, Boulevard cara Lazara 1, 21000 Novi Sad, Republic of Serbia \\ e-mail:vvvesna@uns.ac.rs
}

\begin{abstract}
This study determined the influence of the addition of commercial bakery improver (0.1-0.9\%), table salt (1-7 \%), and white sugar (1-9 \%) into dough on fermentative activity (FA) of yeast, and consequently $\mathrm{CO}_{2}$ production, to improve dough handling and quality of wheat bread by using an optimized additive combination. The FA of yeast cells was evaluated using fermentograph SJA device. The addition of white sugar in the amount of 1-4\% and complex additive in the amount 0.1-0.5 \% enhances FA of yeast. Further increase of the amount of these two compounds decreases the FA. The addition of table salt in the amount of 1-7 \% negatively affected the FA. The optimal amounts of complex additive, table salt and white sugar, obtained by response surface methodology (RSM) using Design Expert software, which provided maximum FA of $1171.31 \mathrm{ml} \mathrm{CO} / \mathrm{gdm} / 2 \mathrm{~h}$ were the following: 0.41, 1.0 and $3.91 \%$ based on flour weight, respectively.
\end{abstract}

Key words: fermentative activity, bakery yeast, Saccharomyces cerevisiae.

\section{REZIME}

Savremena proizvodnja pekarskih proizvoda podrazumeva primenu različitih komercijalnih preparata za poboljšanje fizičkih $i$ hemijskih karakteristika testa, pa samim tim i poboljšanje senzornih i organoleptičkih osobina pekarskih proizvoda sa ciljem da se zadovolje ukus i zahtevi protrošača i dobiju visoko kvalitetni proizvodi uz minimalne troškove. Fermentativna aktivnost (FA) ćelija pekarskog kvasca je jedan od osnovnih faktora koji utiče na fizičku strukturu pekarskih proizvoda. Visoka FA pekarskog kvasca podrazumeva intenzivno oslobađanje ugljendioksida u testu, što za posledicu ima dobijanje pekarskih proizvoda poroznije strukture i boljih organoleptičkih osobina. U ovom radu je utvrđen uticaj dodatka komercijalnog kompleksnog pekarskog poboljšivača (0.10.9\%), kuhinjske soli (1-7\%) i konzumnog šećera (0,9-1\%) u brašno na fermentativnu aktivnost (FA) pekarskog kvasca u testu, odnosno na njegovu sposobnost proizvodnje $\mathrm{CO}_{2}$ u cilju olakšanja obrade i pripreme testa, kao i povećanja kvaliteta pšeničnog hleba dodatkom optimalne kombinacije aditiva. FA pekarskog kvasca određena je SJA fermentografom. Ustanovljeno je da se dodatkom šećera u količini 1-4\% $i$ aditiva u količini 0,1-0,5\% u brašno povećava FA kvasca u testu. Dalje povećanje količine ove dve komponente je negativno uticalo na metabolizam kvasca, odnosno FA. Dodatak kuhinjske soli u količini 1-7\% je negativno uticao na FA kvasca. Opimalne količine aditiva, kuhinjske soli i konzumnog šećera, dobijene metodom odzivne površine (RSM) pomoću softvera Design Expert su: 0,41\%, 1,0 \% i 3,91\% na masu brašna, pri čemu se ostvaruje maksimalna FA kvasca od 1171,31 ml $\mathrm{CO}_{2} / \mathrm{gdm} / 2 \mathrm{~h}$.

Ključne reči: fermentativna aktivnost, pekarski kvasac, Saccharomyces cerevisiae.

\section{INTRODUCTION}

Fermentative activity (FA) of bakery yeast cells is one of the main factors that affect the physical structure of the baked goods. High FA of yeast cells involves intense release of carbon dioxide in the dough. Namely, $\mathrm{CO}_{2}$ produced by yeast causes the gluten to stretch, and some escape, but most of the gas is retained and is trapped within the matrix (Hutkins, 2006). Consequently, it creates foam-like structure of dough that is the prerequisite for a rapid heat flow through the dough, which enables porous structure and better organoleptic properties of baked goods. Further, fermentation rates and yeast cells metabolism are mainly affected by temperature and osmotic pressure. Osmotic pressure in dough can be very high, even 35 to 100 atmospheres, and mainly depends on the proportions of sugar and salt used (Poitrenaud, 2006). The leavening of doughs is highly dependent on osmotolerance of yeast (Oda and Ouchi, 1990). In the dough, carbon sources are constituted of small quantities of glucose, fructose and sucrose. Glucose and fructose can be directly metabolised as they are diffused through the cellular membrane. There is a greater preference for glucose, which is the first to be used in the dough. By decreasing the glucose concentration, the yeast uses the fructose in the dough. The sucrose is hydrolysed to glucose and fructose by yeast invertase in the first minutes of mixing. Therefore, at the end of this process, the dough only has glucose, fructose and maltose. The introduction of sucrose in the dough is a very common practice in bakeries. By introducing this type of diglucid in the dough, we deal with an increase of fermentable glucid quantity. As a consequence, yeast activity is accelerated. The process occurs until a maximum degree of sucrose is added; afterwards, yeast activity is inhibited (Voica and Codină, 2009). Yeasts used in baking are often exposed to high concentrations of sugars. Industrial bakers' yeasts express high levels of invertase activity, which cleaves sucrose rapidly to effectively double osmotic pressure of sweet doughs (Evans 1990). Many large scale bakeries add sucrose (about $1 \%$ to $3 \%$ ) as an additional source of readily fermentable sugars (Voica and Codină, 2009). Sweet 
bread doughs can contain up to $30 \%$ of added sucrose per weight of flour, which exerts a severe osmotic stress (Reed and Nagodawithana, 1991). Table salt is generally considered to be an important chemical compound (additive) in bakery production, since it affects palatability, taste, and the structural and physical properties of bread. The salt is used in bakery production for stabilizing yeast fermentation rate, strengthening the dough, enhancing the flavor of the final product, and increasing the dough mixing time (Miller and Hoseney, 2008). It acts as a seasoning and flavours the dough, as a color enhancer by reducing the action of sugar within the dough, and controls the texture by strengthening the gluten. By slowing down the yeast action, it allows the fermentation to be controlled and retards bacteria growth. High concentration of salt decreases yeast activity in the dough, thus retarding gas production (Lynch et al., 2009). The salt gives strength to the gluten, enabling the dough to efficiently hold carbon dioxide, which is released into the dough as a by-product of the yeast fermentation. On the other hand omitting the salt from the formula results in dough that is slack and sticky in texture, work-up is difficult, bread volume is poor, and bread as final product is quite tasteless (Luchian and Canja, 2010).

Besides white sugar and salt, modern bakery production involves the use of various commercial products to improve the physical and chemical characteristics of the dough, and thus improve the sensory and organoleptic properties of baked goods in order to meet the consumer's tastes and requirements, and produce high quality products at minimum costs. Besides, bread improvers (additives) are used in bakery industry in order to simplify the work of bakers, smooth out the dough more quickly, enhance machinability, and increase yields. Complex improvers include oxidative and reductive substances, enzyme products, emulsifiers, etc. (Davidović et al., 2010). The most widely used oxidative component in the bakery industry is the oxidized form of L-ascorbicacid (DHAA), which greatly impacts the physical properties of gluten by decreasing the time and energy needed for mixing (Lillard and Seib, 1982; Dahle and Murthy 1970). As a strong oxidative medium it induces webbing of the gluten matrix, and improves rheological characteristics of dough (Every et al., 1999). The addition of different kinds of emulsifiers such as mono- and diacylglycerols esterified to mono- and diacetyltartaric acid (DATEM) also called dough strengtheners improves bread characteristics. They substances progress mixing tolerance, gas retention and resistance of the dough to collapse, promote the aggregation of gluten proteins in dough by binding to the protein hydrophobic surface, form lamellar liquidcrystalline phases in water, which associate with gliadins. In effect we can obtain bread with better texture, elasticity, and increased volume (Ribotta et al., 2004). Enzymes, usually amylases are often used in commercial bread improvers because their activity affects dough consistency through the effect on the starch granules which enables softening the dough and improving dough extensibility and gas retention (Dubois et al., 1990).

The addition of table salt, white sugar and commercial bakery improver into dough, affects the metabolic functions of bakery yeast Saccharomyces cerevisiae, and thus its FA. Although there are some studies dealing with the effect of salt or sugar on FA of yeast, the influence of the concurrent interactions of sugar, salt and commonly used commercial additive containing L-ascorbic acid, emulsifiers and enzyme complex on the FA determined by using SJA device has not been reported before. Thus, findings that are concerning the influence of these three commonly used compounds, as well as their combination on the FA of yeast could contribute to gain necessary knowledge for process development and optimization.

\section{MATERIAL AND METHOD}

Throughout the experiment, dough was prepared with domestic wheat flour T-500 (water adsorption capacity 53-57 \%) with an average quality like start material. Flour quality tests indicated following values: $12.1 \%$ moisture, ash $0.42 \%$, protein $0.45 \%$. Flour was taken from a package of $25 \mathrm{~kg}$. Fresh compressed commercial baker's yeast, Saccharomyces cerevisiae (31.7 \% of moisture), was provided by a local producer Alltech-Fermin, Senta. Table salt and white sugar ( $99.7 \%$ pure sucrose) were obtained from local factories. The domestic commercial complex additive was composed of an emulsifier (mono- and diacetyl ester of tartaric acid of mono and diglycerides of fatty acids), anti-caking agent (calcium carbonate), ascorbic acid $\left(\mathrm{C}_{6} \mathrm{H}_{8} \mathrm{O}_{6}\right)$, and enzymatic complex flour as filler. According to the manufacturer recommendations it should be dosed in an amount of from 0.15 to $0.45 \%$ on the weight of flour in the bread making process, and from 0.3-0.5\% to the flour for the production of baked goods. The FA was analyzed according to Serbian standards methods (Pravilnik o kvalitetu i drugim zahtevima za pekarski kvasac ',Sl.list SRJ', br.9/2002 i ',Sl.list SCG', br. 56/2003) following the procedure: $280 \mathrm{~g}$ of flour, sugar (1-9 \% w/w based on flour weight) and commercial complex additive $(0.1-0.9 \% \mathrm{w} / \mathrm{w}$ based on flour weigh) previously heated to $35{ }^{\circ} \mathrm{C}$ were transferred in suitable enamel jug also preheated at $35{ }^{\circ} \mathrm{C}$. Pressed bakery yeast (5 g) was suspended in $160 \mathrm{ml}$ of table salt solution (1-7\% w/w based on flour weigh ) in tap water $\left(35{ }^{\circ} \mathrm{C}\right)$. The mixing was performed on laboratory farinographic mixer during 5 min. Formed dough sample was placed into a preheated mold and transferred to SJA fermentograph chamber at $35{ }^{\circ} \mathrm{C}$. Fermentograph plotter registered the changes in the volume of $\mathrm{CO}_{2}$ during $2 \mathrm{~h}$ of the fermentation. The experimental design and statistical analysis were performed using Stat-Ease software (Design- Expert 7.0.0 Trial, Minneapolis, MN, USA). BoxBehnken design (Andre and John, 1987) was applied to evaluate optimal process conditions and the individual and combined effects of the three independent variables (contact time, initial dye concentration and solution $\mathrm{pH}$ ) on the response (adsorption capacity). The total of 17 experiments were conducted in the study toward the construction of a quadratic model. A quadratic second-degree polynomial equation (1) approximated in this study can be described as:

$$
Y=\beta_{O}+\beta_{1} X_{1}+\beta_{2} X_{2}+\beta_{3} X_{3}+\beta_{12} X_{1} X_{2}+\beta_{13} X_{1} X_{3}+\beta_{23} X_{2} X_{3}+\beta_{11} X_{1}^{2}+\beta_{22} X_{2}^{2}+\beta_{33} X_{3}^{3}
$$

where $Y$ is the response (predicted FA); $X_{1}, X_{2}$ and $X_{3}$ are independent variables (complex additive amount, table salt amount and white sugar amount added in \% on flour weight bases); $\beta_{o}$ is the constant coefficient, $\beta_{1}, \beta_{2}, \beta_{3}$ are linear coefficients, $\beta_{11}, \beta_{22}$, $\beta_{33}$ are the quadratic coefficients, $\beta_{12}, \beta_{13}$ and $\beta_{23}$ are interaction coefficients. The optimization process includes estimation of the coefficients by fitting them in a mathematical model that fits best the experimental conditions, prediction of the fitted model response and checking the adequacy of the model. The levels of chosen independent variables which predominantly affect the extent of yeast FA and the design matrix are given in Tables 1 and 2, respectively. The goodness of fitting and polynomial equations terms significances were determined through appropriate statistical methods (coefficient of determination $R^{2}, F$-value at a probability $P$ of 0.05). The adequacy and significance of the quadratic models was assessed by the analysis of variance (ANOVA). 
Table 1. Values of factors in Box-Behnken design

\begin{tabular}{|c|c|c|c|}
\hline \hline Factor & Name & Low value & High value \\
\hline $\mathrm{X}_{1}$ & Additive $(\% \mathrm{w} / \mathrm{w})$ & 2.0 & 6.0 \\
\hline $\mathrm{X}_{2}$ & Salt $(\% \mathrm{w} / \mathrm{w})$ & 30 & 50 \\
\hline $\mathrm{X}_{3}$ & Sugar $(\% \mathrm{w} / \mathrm{w})$ & 0 & 60 \\
\hline
\end{tabular}

Table 2. Box-Behnken matrix and responses ( $X_{1}$ :complex additive $(\% \mathrm{w} / \mathrm{w}) ; \mathrm{X}_{2}$ : Salt (\% w/w); $X_{3}$ : Sugar (\% w/w); Y: Fermentative activity of yeast cells $(\mathrm{ml} \mathrm{CO} / \mathrm{gdm} / 2 \mathrm{~h})$

\begin{tabular}{||c|c|c|c|}
\hline \hline $\mathrm{X}_{1}$ & $\mathrm{X}_{2}$ & $\mathrm{X}_{3}$ & $\mathrm{Y}$ \\
\hline 0.1 & 1 & 5 & 1174.21 \\
\hline 0.1 & 4 & 1 & 665.17 \\
\hline 0.1 & 4 & 9 & 411.72 \\
\hline 0.1 & 7 & 5 & 128.33 \\
\hline 0.5 & 1 & 1 & 999.89 \\
\hline 0.5 & 1 & 9 & 914.34 \\
\hline 0.5 & 4 & 5 & 755.00 \\
\hline 0.5 & 4 & 5 & 784.94 \\
\hline 0.5 & 4 & 5 & 718.64 \\
\hline 0.5 & 4 & 5 & 748.25 \\
\hline 0.5 & 4 & 5 & 752.45 \\
\hline 0.5 & 7 & 1 & 130.47 \\
\hline 0.5 & 7 & 9 & 67.37 \\
\hline 0.9 & 1 & 5 & 1099.35 \\
\hline 0.9 & 4 & 1 & 643.78 \\
\hline 0.9 & 4 & 9 & 410.65 \\
\hline 0.9 & 7 & 5 & 101.59 \\
\hline
\end{tabular}

\section{RESULTS AND DISCUSION}

Second order polynomial equation has been obtained as a result of following response function:

$Y=1076,01585+283,92991 X_{1}-105,88664 X_{2}+75,71413 X_{3}+$ $10,02567 \mathrm{X}_{1} \mathrm{X}_{2}+3,17489 \mathrm{X}_{1} \mathrm{X}_{3}+0,46786 \mathrm{X}_{2} \mathrm{X}_{3}-378,67245 \mathrm{X}_{1}^{2}-$ $7,26666 X_{2}^{2}-9,90238 X_{3}^{2}$

fitting by multiple regression. The adequacy and significance of the quadratic models were assessed by the analysis of variance (ANOVA) (Table 3). The developed regression model was proved to be significant and adequate $(P<0.05)$, with only $1.15 \%$ of the total variations not explained by the model $\left(R^{2}=0.985\right)$.

Table 3. Analysis of variance (ANOVA) for the experimental results (" significant at $P<0.05 ;{ }^{* *}$ not significant)

\begin{tabular}{|c|c|c|}
\hline & F-value & P-value \\
\hline Model & 50.01 & $<0.0001^{*}$ \\
\hline$X_{1}$ & 0.44 & $0.5288^{* *}$ \\
\hline$X_{2}$ & 403.42 & $<0.0001^{*}$ \\
\hline$X_{3}$ & 11.51 & $0.0115^{*}$ \\
\hline$X_{1} X_{2}$ & 0.13 & $0.7269^{* *}$ \\
\hline$X_{1} X_{3}$ & 0.024 & $0.8823^{* *}$ \\
\hline$X_{2} X_{3}$ & 0.029 & $0.8701^{* *}$ \\
\hline$X_{1}^{2}$ & 3.53 & $0.1024^{* *}$ \\
\hline$X_{2}^{2}$ & 4.11 & $0.0822^{*}$ \\
\hline$X_{3}^{2}$ & 24.11 & $<0.0017^{*}$ \\
\hline \multicolumn{2}{|l}{} \\
\hline
\end{tabular}

Fig. 1-3 presents the response surface plots (3D) of the individual and interactive effects of process parameters on FA. The results presented in Fig. 1 clearly implied that the addition of table salt in the amount 1-7 \% negatively affected the FA, probably as a consequence of osmotic stress. This outcome was expected concerning findings reported previously, implying that the addition of salt in the dough has a retarding effect on the activity of the yeast, and consequently gas formation (Lynch et al., 2009; Lucian and Canja, 2010). This appears to be the result of increased osmotic pressure and the action of sodium and chloride ions on the membrane of yeast cells. However, if there is no salt, the yeast will ferment too quickly resulting in gassy, sour dough and baked products with open grain and poor texture. In this sense, the salt aids in controlling the rate of fermentation (Miller and Hoseney, 2008).

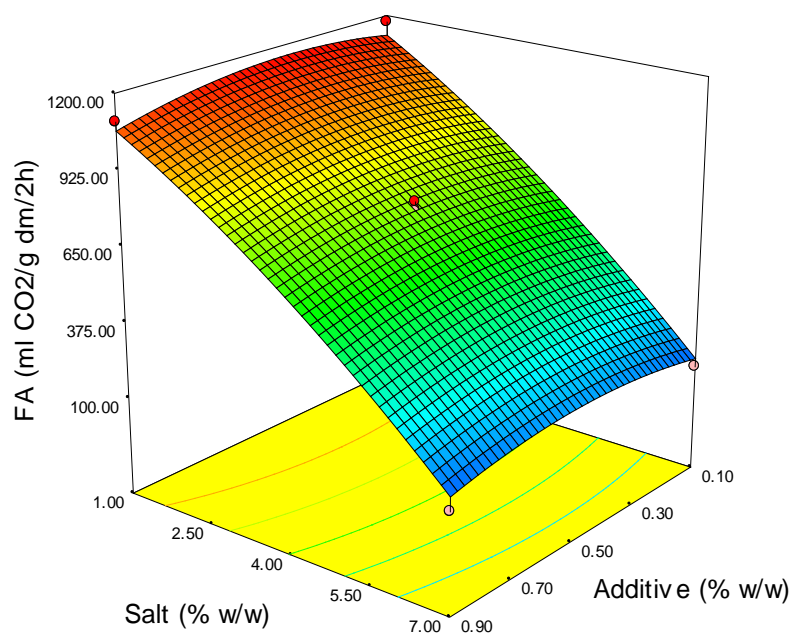

Fig. 1. Response surface plots of the interaction of table salt and complex additive sugar addition on FA.

From Fig. 2 it is notable that the addition of white sugar in the amount of 1-4 \% and complex additive in the amount $0.1-0.5$ $\%$ enhances FA of yeast. Further increase of the amount of these two compounds decreases the FA.

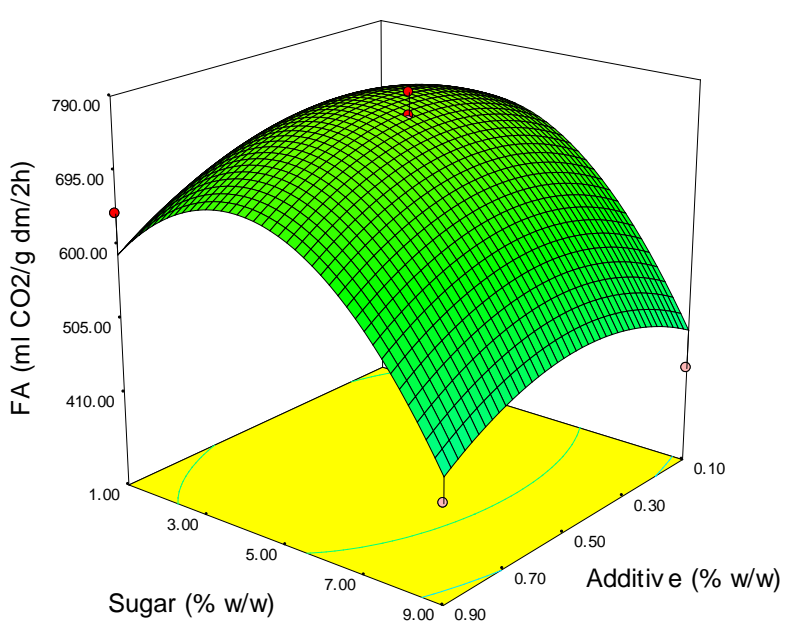

Fig. 2. Response surface plots of the interaction of white sugar and complex additive addition on FA

From Fig. 3, it is obvious that the addition of salt shows more negative influence on FA than the addition of the same amount of sugar. 


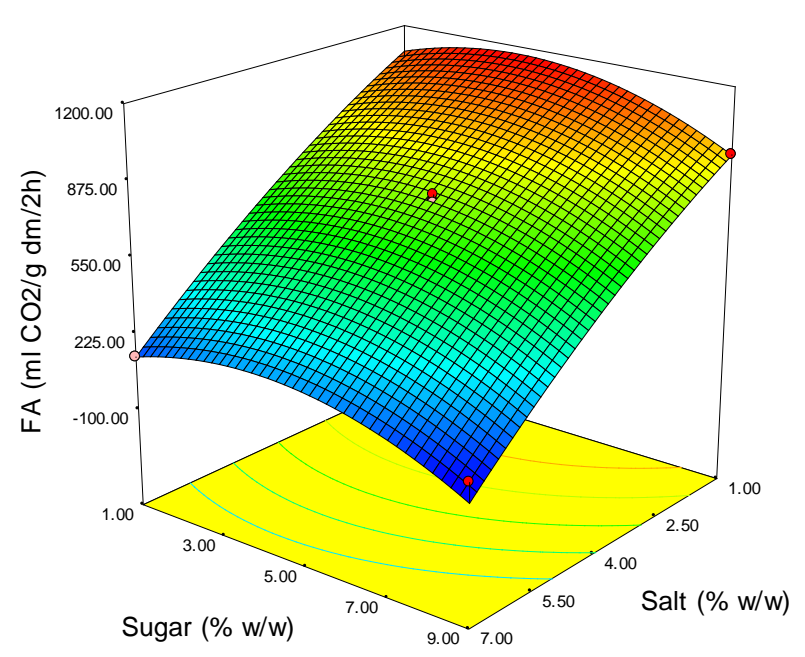

Fig. 3. Response surface plots of the interaction of white sugar and table salt addition on FA

\section{CONCLUSION}

The prediction of optimal reaction conditions was made by use of desirability function concept and Design Expert software. Maximal FA (1171.31 $\mathrm{ml} \mathrm{CO}_{2} / \mathrm{gdm} / 2 \mathrm{~h}$ ) should be ensured with the following amounts of additives: $0.41 \%$ (complex additive), $1.0 \%$ (table salt) and $3.91 \%$ (white sugar) based on flour weight. These findings could contribute to gain necessary knowledge for process development and optimization of bread production from high quality wheat flour commonly used in bakery production. Still, further investigation is needed to explore the addition of these compounds on FA during the bread production from different types of dough such as for example: dough prepared from wheat flour of poor technological quality by substitution of barley and millet flour (Živančev et al., 2016), or flour of wholemeal spelt enriched with plant proteins (Šimurina et al., 2015).

\section{REFERENCES}

Andre, I.K., John, V.C. (1987). Response surface designs and analysis. Marcel Dekker, New York, USA.

Dahle, L.K., Murthy, R. (1970). Some effects on antioxidants in dough systems. Cereal Chemistry 47, 296-303.

Davidović, D., Dodić, S., Mastilović, J., Dodić, J., Popov, S., Lazić, M. (2010). The application of natural organic compounds in bakery industry. Hemijska industrija, 64 (5), 411-421. (2010).

Dubois, K.D. (1980). Enzymes in baking, Technical bulletin, Volume II, Issue 10.

Evans, I. (1990). Yeast strains for baking: recent developments. In Yeast Technology ed. Spencer, J.F.T. and Spencer, D.M. Berlin: Springer Verlag 13-54.

Every, D., Simmons, L., Suton, H.K., Ross, M. (1999). Studies on the mechanism of the ascorbic acid improver effect on bread using flour fractionation and reconstitution methods. Journal of cereal sciences 30, 147-158.

Hutkins, R. W. (2006). Microbiology and Technology of Fermented Foods, Blackwell Publishing, chapter 8, 128-129.

Lillard, W.D., Seib, A.P., Hoseney, C.R. (1982). Isomeric ascorbic acids and derivatives of L-ascorbic acid: their effect on the flow of dough. Cereal Chemistry, 59, 291-296.

Miller, R.A., Hoseney, R. C. (2008). Role of Salt in Baking. In: CFW 53, 4-6.

Poitrenaud, B. (2006). Yeast in Handbook of Food Science, Technology and Engineering, vol. II, edited by Y. H. Hui, USA, chapter 69.

Reed, G., Nagodawithana, T.W. (1991). Yeast Technology, 2nd edn. New York: Van Nostrand Reinhold.

Ribotta, D.P., Pérez, T.G., León, E.A., Añón, C.M. (2004). Effect of emulsifier and guar gum on micro-structural, rheological and baking performance of frozen bread dough, Food Hydrocolloid. 18, 305-313.

Šimurina, O., Brkljača, J., Krulj, J., Jambrec, D., Filipčev, B., Jevtić Mučibabić, R., Pestorić, M (2015). Properties of wholemeal spelt dough and bread enriched with plant proteins Journal on Processing and Energy in Agriculture, 19 (5), 236240.

Voica, D., Codină, G. G. (2009). The influence of sucrose addition on the fermentative activity of compressed yeast and on the quality of bread obtained from weaker-average flour quality in bread making. Scientific papers. Journal Lucrări Ştiinţifice-Agronomy Series, 52 (2), 121-124.

Živančev, D., Torbica, A., Tomić, J., Janić-Hajnal, E. (2016) Possibility of utilization alternative cereals (millet and barley) for improvement tehchnological properties of bread gained from flour of poor technological quality. Journal on Processing and Energy in Agriculture 20 (4), 165-169.

Received: 22. 02. 2017. 